\title{
Masaaki Hirooka: Innovation Dynamism and Economic Growth: A Nonlinear Perspective
}

Edward Elgar Publishing, 2006

\section{Chihiro Watanabe}

Published online: 23 January 2008

(C) Springer-Verlag 2007

Erratum to: JEE (2007) 17: 649-652

DOI 10.1007/s00191-007-0068-2

Erroneously the book Innovation Dynamism and Economic Growth: A Nonlinear Perspective by Masaaki Hirooka is indicated as an edited volume, instead of being a monograph.

Please accept our apologies for this fault.

The online version of the original article can be found at http://dx.doi.org/10.1007/s00191-007-0068-2.

C. Watanabe $(\bowtie)$

Department of Industrial Engineering \& Management, Tokyo Institute of Technology, Tokyo, Japan e-mail: watanabe.c.aa@m.titech.ac.jp 